\title{
Molecular Methods for Detection of Antimicrobial Resistance
}

\author{
Anjum, Muna F.; Zankari, Ea; Hasman, Henrik
}

Published in:

Microbiology Spectrum

Link to article, DOI:

10.1128/microbiolspec.ARBA-0011-2017

Publication date:

2017

Document Version

Publisher's PDF, also known as Version of record

Link back to DTU Orbit

Citation (APA):

Anjum, M. F., Zankari, E., \& Hasman, H. (2017). Molecular Methods for Detection of Antimicrobial Resistance. Microbiology Spectrum, 5(6). https://doi.org/10.1128/microbiolspec.ARBA-0011-2017

\section{General rights}

Copyright and moral rights for the publications made accessible in the public portal are retained by the authors and/or other copyright owners and it is a condition of accessing publications that users recognise and abide by the legal requirements associated with these rights.

- Users may download and print one copy of any publication from the public portal for the purpose of private study or research.

- You may not further distribute the material or use it for any profit-making activity or commercial gain

- You may freely distribute the URL identifying the publication in the public portal

If you believe that this document breaches copyright please contact us providing details, and we will remove access to the work immediately and investigate your claim. 


\title{
Molecular Methods for Detection of Antimicrobial Resistance
}

\author{
MUNA F. ANJUM, ${ }^{1}$ EA ZANKARI ${ }^{2}$ and HENRIK HASMAN ${ }^{2,3}$ \\ ${ }^{1}$ Department of Bacteriology, Animal and Plant Health Agency, Surrey, United Kingdom; \\ ${ }^{2}$ National Food Institute, Technical University of Denmark, Lyngby, Denmark; ${ }^{3}$ Reference Laboratory for \\ Antimicrobial Resistance and Staphylococci, Staten Serum Institut, Copenhagen, Denmark
}

\begin{abstract}
The increase in bacteria harboring antimicrobial resistance (AMR) is a global problem because there is a paucity of antibiotics available to treat multidrug-resistant bacterial infections in humans and animals. Detection of AMR present in bacteria that may pose a threat to veterinary and public health is routinely performed using standardized phenotypic methods. Molecular methods are often used in addition to phenotypic methods but are set to replace them in many laboratories due to the greater speed and accuracy they provide in detecting the underlying genetic mechanism(s) for AMR. In this article we describe some of the common molecular methods currently used for detection of AMR genes. These include PCR, DNA microarray, whole-genome sequencing and metagenomics, and matrix-assisted laser desorption ionization-time of flight mass spectrometry. The strengths and weaknesses of these methods are discussed, especially in the context of implementing them for routine surveillance activities on a global scale for mitigating the risk posed by AMR worldwide. Based on current popularity and ease of use, PCR and single-isolate whole-genome sequencing seem irreplaceable.
\end{abstract}

\section{INTRODUCTION}

Molecular characterization of the genetic mechanism(s) underlying a given phenotypic result, obtained by traditional antimicrobial sensitivity testing, is now an integral part of many clinical investigations in relation to bacterial infections, whether in humans or animals. In some cases, when phenotypic results are too time-consuming, nonconclusive, or unavailable, molecular analysis can be used to investigate the presence of a given gene or point mutation and thereby give direct support to ensure that an optimal treatment or control strategy is undertaken in a timely manner. In addition, molecular characterization is frequently used as an indirect method to aid in epidemiological investigations following an outbreak, when phenotypic data is not sufficiently detailed to control possible outbreaks involving resistant bacteria. Finally, molecular characterization of antimicrobial resistance (AMR) determinants is also used for local, national, or even global surveillance of AMR. Currently, the European Food Safety Authority (EFSA) and the European Center for Disease Control (ECDC) are involved in monitoring and coordinating surveillance of AMR in important zoonotic bacteria from food animals and humans, and systems such as the European Antimicrobial Resistance Surveillance System (EARSS) have helped generate data regarding the prevalence of AMR in many European countries. However, most of the data are based on phenotypic characterization of isolates, although genotypic detection of AMR genes is also being increasingly performed by member states.

Discussing phenotypic detection of AMR in bacteria is not meaningful unless the purpose of the analysis is defined. In relation to treatment of clinical infections, parameters such as sites of infection, clinical manifestation, and toxic concentration of the antimicrobial agent used need to be considered to define a relevant clinical

Received: 4 February 2017, Accepted: 7 June 2017,

Published: 7 December 2017

Editors: Frank Møller Aarestrup, Technical University of Denmark, Lyngby, Denmark; Stefan Schwarz, Freie Universität Berlin, Berlin, Germany; Jianzhong Shen, China Agricultural University, Beijing,

China, and Lina Cavaco, Statens Serum Institut, Copenhagen, Denmark

Citation: Anjum MF, Zankari E, Hasman H. 2017. Molecular methods for detection of antimicrobial resistance. Microbiol Spectrum 5(6): ARBA-0011-2017. doi:10.1128/microbiolspec.ARBA-0011-2017. Correspondence: Muna F. Anjum, Muna.Anjum aapha.gsi.gov.uk (c) 2017 American Society for Microbiology. All rights reserved. 
breakpoint, which distinguishes between treatable (sensitive), potentially treatable (intermediate resistant), and nontreatable (resistant) infections. Alternatively, the epidemiological cutoff, or ECOFF, can be used to differentiate between the wild type, fully susceptible populations of bacteria, and bacteria with reduced susceptibility due to an acquired resistance mechanism.

Acquired resistance to antimicrobial agents is correlated with a multitude of molecular mechanisms depending on the organism and the antimicrobial agent involved. These mechanisms include very different genetic events such as constitutive or inducible expression of (acquired) resistance genes, upregulated expression of resistance genes because of mutations in the promoter/regulator region, and insertion of strong active promoters as part of, e.g., insertion elements upstream of the resistance gene, mutations in housekeeping genes acting as targets for antimicrobial agents, and loss-offunction mutations in regulatory elements or specific porins (1). In addition, bacteria can be intrinsically resistant to certain types or even whole classes of antimicrobial agents when these are given in therapeutic concentrations. For example, enterococci are inherently resistant to cephalosporins, partly due to low binding affinity of the penicillin binding protein 5 , which is involved in cell wall synthesis in this organism (2). Common causes of intrinsic resistance are lack of (or low affinity to) the target for the antimicrobial agent, an inability of the drug to access the target, expression of chromosomally located resistance genes encoding enzymes, and the presence of multidrug efflux pumps (3).

Because of the large diversity of possible mechanisms involved in reduced antimicrobial susceptibility, it is not a trivial task to transform all of these mechanisms or genes into sequence-based detection algorithms if genotypic methods are eventually to substitute for phenotypic methods, especially because new genes or allelic variants of current resistance mechanisms are continuously being discovered. In the case of intrinsic resistance, a priori knowledge of a given organism is required to predict if it is intrinsically resistant to certain antimicrobials, which makes translation of sequence-based data into predicted susceptibility even more complicated. For example, anaerobic bacteria are intrinsically resistant to aminoglycosides, while Helicobacter pylori is intrinsically resistant to metronidazole and Pseudomonas aeruginosa shows natural resistance to sulfonamides and trimethoprims (4-6). Conversely, some genetic resistance mechanisms are inherently difficult to detect by classical in vitro phenotypic methods and can therefore remain undetected, even though they can lead to treatment failure in vivo, thereby increasing the importance of detecting these mechanisms by molecular methods. This is evident for Gram-negative pathogens carrying the $b l a_{\text {OXA-48 }}$ gene, often conferring only a minor reduction in their susceptibility to carbapenems (ㄱ), and some clonal lineages of methicillin-resistant Staphylococcus aureus (MRSA), where heterologous expression of the $m e c A$ gene can lead to inconclusive interpretation of the organism's susceptibility to beta-lactams ( $\underline{8})$.

Despite the varied challenges posed by genotypic detection of mechanisms leading to reduced susceptibility to different antimicrobial agents, molecular methods are being used extensively by both research and reference laboratories. Some of the methods employed, such as PCR and hybridization techniques, have been used for decades, while new methods such as whole-genome sequencing (WGS) and matrix-assisted laser desorption ionization-time of flight mass spectrometry (MALDITOF MS) are just emerging. The most commonly used modern molecular methods in relation to detection of determinants involved in conferring reduced susceptibility to antimicrobial agents are discussed in this article. The main advantages and disadvantages of using the different genotypic methods for detecting AMR will be described individually below; a more elaborate discussion of these methods has been published recently ( $)$.

\section{PCR}

PCR is a technique that was developed in the 1980s by Kary Mullis (10) and has revolutionized molecular biology, enabling rapid and exponential amplification of target DNA sequences using a forward and reverse PCR primer and an enzyme known as DNA polymerase in the presence of deoxyribonucleotides. Conventional PCR comprises three steps: (i) denaturing of the doublestranded DNA at $95^{\circ} \mathrm{C}$, (ii) annealing of the PCR primers at 50 to $60^{\circ} \mathrm{C}$, and (iii) extension of the DNA at $72^{\circ} \mathrm{C}$. PCR is used routinely in microbiology laboratories for detecting any genes that may be present within bacteria, as long as a DNA sequence is available for the whole or partial gene which can be used to design the PCR primers. The PCR-amplified gene product can be visualized by running agarose gels and staining DNA with ethidium bromide or other fluorescent DNAchelating dyes. The whole process, including amplification and visualization, can take between 4 and $5 \mathrm{~h}$.

Since the development of PCR, there have been several advances, which include real-time PCR (RT-PCR) and isothermal amplifications, e.g., loop-mediated iso- 
thermal amplification (LAMP) and recombinase polymerase amplification (RPA). The main difference between conventional PCR and RT-PCR is that in the latter, amplification of the target DNA sequence is monitored in real time as it occurs, rather than at the end, due to the presence of fluorescent dyes in the reaction, and thus is also known as quantitative PCR (qPCR). Therefore, in RT-PCR, agarose gel electrophoresis is not required; this can save considerable time and is safer, because the use of ethidium bromide, which is a carcinogen, is not required. RT-PCR can use either (i) nonspecific dyes that intercalate with any doublestranded DNA or (ii) sequence-specific DNA probes consisting of oligonucleotides that are labeled with a fluorescent reporter which permits detection only after hybridization of the probe with its complementary sequence (11). Isothermal PCR techniques such as LAMP and RPA, in contrast, differ from conventional or RTPCR in that the whole process is performed at a constant temperature and does not require ramping up and down of temperatures. For LAMP, the temperature is around $65^{\circ} \mathrm{C}$, while it is around $40^{\circ} \mathrm{C}$ for $\mathrm{RPA}$; up to six different primers are used for LAMP, whereas RPA uses two primers $(12,13)$. The presence of intercalating dyes in the reaction allows fluorescent detection of target DNA amplification in real time using a real time PCR machine, which can be considerably faster than PCR or RT-PCR. However, LAMP and RPA PCR amplification can also occur using a simple water bath or heating element and be measured by photometry for turbidity, which makes both methods amenable for point-of-care applications and use in low-resource settings (14).

Multiplex PCR, in which several target DNA fragments are amplified simultaneously, can be performed using either conventional or RT-PCR. The application of PCR for monitoring multiple AMR genes in bacteria has become easier with the use of multiplexing, and this technique is widely used today, where appropriate, to replace PCR and RT-PCR applications to amplify single genes. In a multiplex PCR assay, several resistance genes can be detected simultaneously with different primers included in the assay mix. The products must be of different sizes and can be visualized either by gel electrophoresis, if from conventional PCR, or by addition of different dyes for RT-PCR. Multiplex PCRs are often designed to detect different genes, all relating to the same resistance phenotype such as detection of the most prevalent beta-lactamases present in Gram-negative bacteria which are involved in resistance to cephalosporins $(\underline{15})$ or carbapenems $(\underline{16}, \underline{17})$. Therefore, by screening for these genes simultaneously, considerable time and effort can be saved in detecting the possible mechanism(s) responsible for the resistance phenotype.

The robustness of any PCR strategy relies on multiple factors such as optimal primer design, GC content of the target template, and presence of inhibitory molecules in the sample. The primers require close to $100 \%$ identity to the target DNA and are thus sensitive to the presence of single nucleotide polymorphisms within the binding sequence, especially at the $3^{\prime}$ end of the primer, where elongation initiates. It is therefore important to select primers in binding areas with low or no nucleotide variation. To ensure the robustness of new PCR assays, a thorough validation process should always be performed to evaluate the specificity (number of falsepositive results) and sensitivity (number of false-negative results) of the assay. Designing primers is relatively easy, but to ensure that these primers have both a high specificity and high sensitivity is not a trivial task, because this requires access to a diverse sequencing dataset representing the variation expected to be present in the test material. If multiplexing is also required, software programs can be employed to help in defining relevant sets of primer pairs (18). Finally, both a positive and a negative control are required every time a PCR assay is performed, to ensure that the sensitivity and specificity are maintained each time the assay is performed.

Conventional PCR assays are well suited to detect the presence or absence of (resistance) genes but are less suited for detection of point mutations within target genes, unless subsequent Sanger sequencing is performed to detect these mutations. RT-PCR can detect single point mutations in a given gene if sequence-specific DNA probes targeting the mutation area are used. However, an advantage that conventional PCR has over RT-PCR is that the latter can only be used to detect the presence of short fragments of DNA, optimally up to $150 \mathrm{bp}$, whereas conventional PCR can easily detect much larger fragments.

\section{AMR Gene Detection}

The use of PCR to detect the presence of AMR genes in a bacterial isolate or even in samples from different environments is commonplace. Due to the ease of designing conventional PCR primers, there are a plethora of PCRs that have been used to detect the presence of different AMR genes from bacteria, in both aerobes and anaerobes. A highly cited paper in this area is by Schwartz et al. (19), who discuss PCR used to monitor for the presence of vanA (encoding vancomycin resistance), $m e c A$ (encoding methicillin resistance), and $a m p C$ (encoding ampicillin resistance) in wastewater systems and 
water biofilms. The authors found the vanA gene in both wastewater and drinking water biofilms, with the van $A$ gene being found in the latter in the absence of enterococci. While mecA was only detected in hospital wastewater, $a m p C$ was the most widespread and was present in wastewater, surface water, and drinking water biofilms. Another paper is one by Lévesque et al. (20), which describes PCR mapping used to determine AMR genes and the order in which they were present in integron cassettes. In 1995, when this paper was published, integrons were a new type of mobile element, and this work was quite novel. A comprehensive, although not exhaustive, list of primers to detect AMR genes is available at the website of the European Reference Laboratory for Antimicrobial Resistance (EURL AMR) in bacteria from animals and food (http://www.eurl-ar .eu/data/images/faq/primerliste\%20til\%20web_07.11 $.2013 . p d f)$.

Conventional PCR has also been used to detect resistance genes in bacteria during infection to antibiotics used in first-line therapy such as those associated with extended-spectrum beta-lactamase (ESBL) resistance (21-23). These PCR assays are often performed in addition to antimicrobial susceptibility testing of the isolates because PCR results can be obtained more quickly, enabling control measures or accurate treatment. More recently, both PCR and RT-PCR have been used widely across Europe and for rapid large-scale epidemiological surveillance of archived bacterial isolates to look for the presence of the plasmid-mediated $m c r-1$ and $m c r-2$ genes harboring plasmid-mediated resistance to antibiotics of last resort such as colistin, which has attracted much interest since its detection and reporting in 2015 (2431). As demonstrated by the colistin outbreak, the use of RT-PCRs as a rapid, easy, and cheap method for targeting AMR gene detection during outbreak response remains unrivalled by any other technology (28).

Examples of the application of multiplex PCR for detecting AMR genes in clinical samples include studies by Strommenger et al. (32) and Chung et al. (33), in which the resistance present in multidrug-resistant $S$. aureus was determined by conventional PCR or in which a multiplex RT-PCR was employed to detect the presence of mecA and species-specific genes. Another example is a multiplex PCR which is used routinely for surveillance in reference laboratories to detect some of the most prevalent ESBL genes: blaTEM, blaSHV, blaCTX-M, and blaOXA (34). Using this multiplex PCR, Randall et al. (35) determined the prevalence of ESBL-producing Escherichia coli strains present in pigs at slaughter in the United Kingdom in 2013 to be
$23.4 \%$. They also showed that blaCTX-M was the most common ESBL type present in these isolates; Sanger sequencing of the PCR product showed CTX-M-1 to be the most prevalent variant to be carried by these isolates, although some CTX-M-15 were also detected.

LAMP assays for the detection of resistance include several assays which have been developed for detecting genes encoding resistance to antibiotics for first-line therapeutics or antibiotics of last resort. Examples include LAMP assays developed for the detection of ESBLs, AmpC genes, and carbapenemases in bacteria purified from both humans and animals $(12,36)$. Due to the rapidity of LAMP assays and the ease of conducting them at a constant temperature, several LAMP assays have been developed (blaVIM, blaNDM, blaKPC, OXA-48 family, CTX-M-1 family, and CTX-M-9 family) to detect carbapenemase and ESBL-producing Enterobacteriaceae using the eazyplex SuperBug CRE system (Amplex Biosystems GmbH, Giessen, Germany) (36). As with PCR, LAMP assays can be used to look for the presence of ESBL genes in a bacterial community rather than in single isolates. For example, Kirchner et al. (37) have used LAMP assays to determine the presence of blaCTX-M genes in lysates made from the mix of bacteria present in overnight enrichment broths prepared from neck flap and cecal samples from poultry carcasses collected at an abattoir. The results showed that just less than a third of the ceca from poultry carcasses were contaminated with bacteria harboring the blaCTX-M gene, but this figure was much higher in skin flaps $(>60 \%)$, probably due to cross-contamination.

\section{DNA MICROARRAY TECHNOLOGY}

DNA microarrays are genomic tools which have been used successfully in the past decade to assess bacterial genomic diversity by detecting the presence or absence of genes in a test organism in comparison to a reference strain or genes. The DNA microarray technology was initially based on glass slides that were spotted with thousands of specific DNA probes based on genes present in one reference strain for which a whole-genome sequence was available. As more isolates of a particular species or genus were whole-genome sequenced, the numbers of probes present on the microarray slide increased substantially to represent accessory genes not present in the reference strain that were part of the "pangenome." Comparative genomic hybridizations were performed whereby test and reference isolate DNA were fluorescently labeled and hybridized to a microarray slide (38). The presence or absence of genes in the test 
isolate, in comparison to a reference, was determined by analyzing the hybridization results. This method enabled comparison of the genomic diversity in a relatively large number of test isolates (tens to hundreds) for which WGS was not available. Examples include E. coli and Salmonella, for which a large number of studies were performed looking at AMRs (39-41).

However, the use of glass slides and fluorescent dyes made the process expensive and time-consuming. Furthermore, there were several advancements in the technology. Although a number of different technologies were available and are reviewed in more detail elsewhere, especially in the context of AMR (42), in this section we will concentrate on that available from Alere Technologies. The Alere microarrays had several advantages that made them suitable for use in routine diagnostic laboratories, which may receive hundreds of samples. Advantages included adaptation of the microarray slide containing DNA probes to a simpler platform such as the bottom of an Eppendorf test tube or a 96-well plate, the use of horseradish peroxidase instead of expensive fluorescent dyes, simple protocols which enable large numbers of test sample DNA to be processed more rapidly and economically, and no requirement for dual hybridization including test and reference. However, disadvantages included the numbers of DNA probes that could be printed in comparison to the full microarray glass slide, which were a few hundred instead of several thousand. In addition, this platform is not suitable for detecting gene expression, but only gene presence and absence, due to inclusion of a preamplification step during labeling of the test DNA prior to hybridization.

\section{AMR Detection Using Microarrays}

Several groups have used the Alere microarrays to investigate AMR and virulence genes that may be present on mobile genetic elements such as plasmids and transposons and can be coselected. Characterization of enteric pathogens and commensals such as field and clinical isolates of both human and animal origin is important in understanding the dissemination these genes by zoonotic bacteria that may ultimately affect human health and therapeutics. This application was first developed by the Animal and Plant Health Agency (formerly the Veterinary Laboratories Agency) in collaboration with Alere through Identibac for determining virulence genes present in $E$. coli to distinguish between pathogenic and commensal E. coli (43), but later it was applied for detecting AMR genes in E. coli and Salmonella from food animals, as well as from human clinical isolates in several studies (44-50). Examples of the use of these microarrays include the characterization of animal isolates collected through surveillance studies, which revealed that AMR genes in Salmonella and E. coli may be present on different mobile genetic elements such as plasmids and Salmonella genomic island $1(\underline{48}, \underline{51})$.

The Identibac microarrays have been used to determine the presence of AMR genes in both aerobic and anaerobic Gram-negative bacteria isolated from healthy human feces in two longitudinal studies performed with a cohort of healthy human subjects in the United Kingdom and Sweden over 1 year following a course of antibiotic treatment, as part of a European Commission 7th Framework Program project called Antiresdev (45, 52-54). Analysis of isolates from feces purified preantibiotic treatment indicated widespread presence of AMR genes in healthy individuals aged between 20 and 60, from both the Swedish and United Kingdom groups, with certain AMR isolates persisting over time. Following treatment, an effect was seen in individuals treated only with amoxicillin, in which a temporary increase in the number of isolates harboring the betalactamase gene blaTEM was seen in the treated group but not in the placebo group. No other antibiotic had such a profound effect $(45,53)$. Examination of anaerobic gut microbiota for mobile genetic elements associated with aerobes, to determine if the former acts as an AMR "sink," indicated that these genes were uncommon in anaerobes and that only the sul gene, encoding resistance to sulfonamide, was present in Bacteroides; however, the genetic element which may be associated with the sul gene could not be determined (54). It would be of interest to perform a similar type of study on farms, to determine if certain AMR bacteria and genes persist on farms over time and the possible risk to food safety associated with such persistence.

Another application of the Identibac AMR microarrays has been to look at the resistome of the microbiota, i.e., the AMR gene content present in the whole microbial population rather than in individual isolates, using human DNA. In a study by Card et al. (55), the resistomes present in the oral and fecal microbiota of humans from five countries were compared using the microarray. The results showed the prevalence of AMR genes associated with anaerobic bacteria such as tet $X$ and $e r m B$, as well as blaTEM and sul2, which are common in aerobic bacteria, present in the majority of samples. Interestingly, a functionally based screening approach which was also undertaken by the authors to determine the genetic context of the AMR genes such as blaTEM and sul 2 that were detected in the microbiota 
only recovered chromosomal genes. This is probably because AMR genes such as blaTEM and sul2 are present in sufficient abundance to be detected by microarray, which employs a linear multiplex amplification process, but are nevertheless not present in high enough abundance to be present in the bacterial artificial chromosome functional libraries that were prepared. It was therefore indicated that microarrays may be more suited to detect AMR genes present on mobile genetic elements which may be present in low copy numbers than a functional genomic approach, although microarrays may be less sensitive than next-generation sequencing methods, in which the depth of sequencing can be very high (see "Whole Genome Sequence Analysis to Detect AMR"). Although in the above study the human oral and fecal microbiota was used, this technique can be applied to any sample, including from farm animals and the environment.

Other microarrays that have been described for determining AMR include those based on glass slides, which for example, have been applied for the characterization of virulence and AMR genes present in Salmonella strains of human clinical relevance (56). There are also arrays in which AMR genes associated with both Gram-positive and Gram-negative bacteria are present. One such array was developed for diagnostic and surveillance activities and was used to test $S$. aureus isolates recovered from milk samples from dairy farms in Quebec, Canada (57). Other organizations, including Alere, have also developed microarrays for detection of virulence and AMR in $S$. aureus isolates recovered from hospital, community, and farm settings (58-64). These arrays are still widely used in both human and veterinary settings.

\section{WGS ANALYSIS TO DETECT AMR}

Like PCR and microarrays, WGS has the potential to detect genetic determinants (genes and mutations) conferring AMR (65, 66). The main advantage of using WGS for this purpose is the ability to cover many different targets at the same time and to subtype specific gene variants. The current WGS technology and methodology for analysis offers similar results as well as some of the same shortcomings as PCR (followed by Sanger sequencing of amplicons) and microarrays, which will be described and discussed in detail below. However, as opposed to microarrays, WGS also offers the possibility to rapidly add new target sequences to the analysis database as well as the ability to perform fast in silico reanalysis on already sequenced isolates (26).

\section{Current Technologies and Bioinformatic Tools} Sequencing platforms

WGS data are generated on highly sophisticated sequencing platforms, which produce large amounts of sequence data compared to the traditional Sanger sequencing technology. Today, the most common platforms for high-throughput sequencing of bacterial genomes are Illumina and Ion Torrent machines, which perform what has been called second-generation or nextgeneration sequencing (as opposed to traditional Sanger sequencing). Common to these machines is that the output consists of relatively short reads (100 to $400 \mathrm{bp}$, depending on the technology), which in most cases are shorter than the genes conferring resistance to antimicrobial agents. Also, the rate of randomly occurring, as well as methodology-based, sequencing errors on single reads originating from the next-generation sequencing technology is relatively high compared to errors encountered with traditional Sanger sequencing. To overcome this problem, a huge surplus (termed $x$-fold coverage) of short-read data is produced for each genome and used for error correction by majority calling. This surplus of (overlapping) short-read data can be either mapped onto known references (reference assembly) or used to build larger fragments (de novo assembly) of sequence data (so-called contigs), which are combined to constitute the draft genome of the isolate (67-69).

An important prerequisite to detect the presence of any relevant gene, including genes conferring resistance to antimicrobial agents, is that the quality and quantity of short reads are large enough to ensure that a given gene is being correctly detected by downstream analysis to avoid false-negative results. Due to the potentially high sensitivity of the analysis methods used for WGS, another important consideration is to ensure that the WGS data do not contain any traces of contaminant DNA, because this can lead to falsepositive results. Unfortunately, low levels of DNA from intraspecies contamination can be very difficult to detect, and good laboratory practice when preparing the DNA and sequencing libraries, in combination with extensive use of appropriate negative controls, is often the best way to avoid, or at least minimize, contamination issues $(70)$. When WGS data from an isolate are found free of contaminants and obtained with a sufficiently high quality and quantity to ensure that relevant genetic information is unlikely to be missing, they can then be used to search for genetic determinants related to AMR (67; http://www.phgfoundation.org/file $\underline{16848 /)}$. 
Bioinformatic approaches for using WGS data to detect genetic determinants related to AMR

Extracting the relevant information to detect genetic determinants related to decreased antimicrobial susceptibility from WGS data is far from being a simple task. The main challenges are (i) to obtain comprehensive databases containing the relevant DNA or protein sequence targets and (ii) to apply appropriate bioinformatic methodologies to accurately extract the relevant information from WGS data based on these target databases. Target databases for WGS analysis are in principle not much different from primer lists directed toward certain PCR targets or DNA probes attached to microarrays as described in the sections above, even though WGS databases have the potential to contain more targets than most PCR or microarray systems. In many instances, a clear correlation between a specific resistance phenotype and a given (resistance) gene exists and has been well-characterized by another method, e.g., PCR or microarray, which makes it relatively easy to include these genes in a target database. However, the task of building a comprehensive database covering all possible genetic variations for a given AMR phenotype is far more complicated. As mentioned above, many genetic mechanisms can be accountable for the AMR phenotype, and a plethora of genetic mechanisms are responsible for resistance phenotypes to different antimicrobial agents. For many of these mechanisms it is difficult to generate simplified in silico decision rules for prediction of their corresponding resistance phenotype, especially because some bacterial species employ specialized mechanisms, which may not even be wellcharacterized or generally applicable beyond a given species (71). Therefore, many of the bioinformatic tools to detect genetic determinants conferring reduced antimicrobial susceptibility are based on target databases containing well-defined genes or specific single point mutations, where a strong correlation between the genetic determinant and a given phenotype exists and can be extracted from either published peer-reviewed articles or from pre-existing archives such as the Antibiotic Resistance Gene Database (ARDB) (https://ardb.cbcb.umd .edu/). A disadvantage of such target databases is that they are based on a priori data and are therefore not suitable for detecting completely new genes families, novel genes, or new point mutations. Also, a constant curation of the target database is required to maintain updates when new genes are published.

Because comprehensive knowledge of genetic determinants for AMRs varies among bacterial species, the sensitivity of gene-based target databases can be too low to be applied for WGS as a first-line decision tool for treatment due to the risk of false-negative results. To unveil the current status of employing WGS data for antimicrobial susceptibility testing, EUCAST recently initiated a consultation involving leading experts in the field (71; http://www.eucast.org/fileadmin /src/media/PDFs/EUCAST_files/Consultation/2016 /EUCAST_WGS_report_consultation_20160511.pdf). Here, the applicability of WGS for this purpose was thoroughly evaluated in relation to the most common human pathogens, with the main conclusion being that the available published evidence does not currently support the use of WGS inferred susceptibility to guide clinical decision making. However, target databases can still be a valuable tool for local, regional, and global surveillance of AMR, because they offer unprecedented resolution of gene variants, which are difficult to obtain by phenotypic as well as most other genotypic methods. Finally, a WGS-based approach enables fast in silico reanalysis of existing data each time the database is updated to ensure backward screening for the presence of new genes or single nucleotide polymorphisms. This approach was successfully used to rapidly reanalyze existing WGS data from Denmark shortly after the first report of the emergence of a mobile colistin resistance gene from China, termed $m c r-1$ (24). Here, the $m c r-1$ gene was retrieved from GenBank as soon as it became available and was added to the ResFinder database, described below, which was used in combination with the CGE Bacterial Analysis Platform (72) to reanalyze 534 bacterial genomes from humans and 380 bacterial genomes from animal and food samples within 2 days after the release of $m c r-1$, thus enabling detection and reporting of $m c r-1$ to the scientific community outside China within 3 weeks of the original publication (26).

The two most common bioinformatic approaches to detect the presence of relevant genes are so-called mapping analysis of raw sequencing reads and BLASTbased analysis of (de novo assembled) draft genome contigs against a reference target database (67). In general, the reference mapping approaches using raw reads are more sensitive than BLAST-based analysis of draft genomes when it comes to detecting AMR genes because de novo assembly is not required for reference mapping. The lower sensitivity of the BLAST-based approach is most likely to be caused by the inability of de novo assembler algorithms to assemble all reads into complete genes, either because the raw read coverage of the particular DNA segment containing the resistance gene is too low for full assembly or because several resistance genes with almost identical sequences are present in the 
isolate, which will cause most assemblers to split the sequence into separate DNA fragments, thus also splitting the resistance gene (73). Conversely, the higher sensitivity of the mapping algorithms is more prone to produce false-positive results from samples with undetected contamination, because the contaminating DNA may not always be assembled into full-length genes by the de novo assemblers and therefore may not be reported by the BLAST alignment, but the algorithm will still be able to map to the target genes, though potentially with lower coverage than correctly mapping reads.

\section{Currently available bioinformatic tools to detect genetic determinants for AMR}

The number of freely available bioinformatic tools for detecting genetic determinants for AMR in WGS data is constantly increasing. The tools are available as web services, as standalone programs to be downloaded on a local computer through a graphical user interface, or as command-line tools, which means that the user is required to download the program and run it commandline on a computer running a Unix-based operation system. A selection of the most commonly used, publicly availably tools will be presented below and summarized in Table 1. A more exhaustive list and in-depth presentation and discussion of bioinformatic tools for detecting molecular mechanisms conferring reduced susceptibility to antimicrobial agents has recently been published (74). In addition, some of the target databases, which these tools are using for detection, have been implemented into commercial software solutions such as the CLCbio Genomic Workbench from Qiagen (http://www.qiagen .com) and the Bionumerics Seven software from Applied Math (http://www.applied-maths.com). Below, only the noncommercial solutions will be presented and discussed in more detail. However, the numbers and diversity of AMR tools are vast, with many government and research institutions using their own custom-made databases and analytical approaches, some of which may not be publicly available $(\underline{27}, \underline{75}-\underline{79})$.

\section{ResFinder}

ResFinder (65) is a web server composed of a BLASTbased alignment for detection of acquired AMR genes in assembled WGS data and a curated database in FASTA format containing the resistance genes. The BLAST output is sorted, so only the best hit within a given position in the data, with a 30-bp overlap allowance, is given as a result. This makes it possible to detect the same gene located in multiple positions of the genomic data. ResFinder allows user selection of the minimum percent identity and minimum percent length of the sequence alignment and reports only the best hit for each gene target which meets these parameters. The ideal percent identity and percent length to employ are dependent on the purpose as well as the quality and type of sequence data.

ResFinder allows upload of both preassembled genomes as well as raw data from various sequencing platforms; when raw WGS data is uploaded, it is assembled by Velvet before being analyzed by ResFinder. ResFinder has been included in a web service called the CGE Bacterial Analysis Platform to allow for automated bulk analysis (72).

Because ResFinder detects only acquired genes, it does not detect genetic elements such as chromosomal mutations and multidrug transporters, as well as intrinsic resistance genes. This makes ResFinder well suited for surveillance of AMR in relation to acquired mechanisms but less suited to be used as an alternative for phenotypic antimicrobial sensitivity testing in the clinic.

\section{CARD}

The Comprehensive Antibiotic Resistance Database (CARD) is a web service and has two analysis options: BLAST and RGI (Resistance Gene Identifier) (0ㅜ, $\underline{81}$ ). The BLAST option performs standard BLAST searches on smaller sequences uploaded by the user (but not whole genomes) against the CARD reference sequences. The RGI supports two detection model types: (i) protein homolog models, which employ BLAST sequence similarity cutoffs to detect AMR genes, and (ii) protein variant models for detection of mutations conferring AMR. Currently, the RGI only analyzes protein sequences, and if assembled contigs are submitted to the tool, the RGI first predicts open reading frames and then analyzes the predicted protein sequences. The RGI is also developed as a command-line tool for bulk analysis of many genomes simultaneously.

\section{ARG-ANNOT}

Antibiotic Resistance Gene-Annotation (ARG-ANNOT) (66) uses a local BLAST algorithm in conjunction with the BioEdit software (http://www.mbio.ncsu.edu/BioEdit (bioedit.html), which allows the user to analyze sequences on a local computer without Internet access once the software is installed. Unfortunately, BioEdit does not currently run on Mac OS environments. ARG-ANNOT provides the user with three databases in FASTA format with phenotypic information in the FASTA header, acquired AMR genes with nucleotide or protein sequences, and a mutational gene database. Currently, the ARG- 


\section{Molecular Methods for Detection of Antimicrobial Resistance}

TABLE 1 Overview of different open-access bioinformatic tools for identification of antimicrobial resistance

\begin{tabular}{|c|c|c|c|}
\hline Method & Method for gene detection & Database & Reference \\
\hline ARG-ANNOT & $\begin{array}{l}\text { Local BLAST program in Bio-Edit software. } \\
\text { Program is downloaded and run on users } \\
\text { computer does not work on MAC } \\
\text { User selective settings, \% identity } \\
\text { Analyzes assembled data } \\
\text { Analyze without Web interface } \\
\text { User sort output results } \\
\text { Possible to run with user-created database }\end{array}$ & $\begin{array}{l}\text { FASTA format } \\
\text { Three databases: } \\
\text { Nucleotide sequences for acquired resistance } \\
\text { gene database and corresponding protein } \\
\text { database } \\
\text { Mutational gene database } \\
\text { Do not state when/if the databases are updated }\end{array}$ & $(\underline{66)}$ \\
\hline CARD & $\begin{array}{l}\text { Analyzes assembled data } \\
\text { Two analysis tools; BLAST and RGI } \\
\text { BLAST method } \\
\text { BLASTn, BLASTp, BLASTx, tBLASTn, tBLASTx } \\
\text { Against CARD protein or nucleotide database } \\
\text { RGI (currently only analyze protein sequences) } \\
\text { Uses BLAST and curated SNP matrices } \\
\text { Possible to download: } \\
\text { RGl command-line tool to bulk analyze (Unix) } \\
\text { Heatmap } \\
\text { BLAST output (excel) } \\
\text { ORFs FASTA }\end{array}$ & $\begin{array}{l}\text { FASTA format } \\
\text { Four nucleotide databases with corresponding } \\
\text { protein databases } \\
\text { Resistance genes and mechanisms } \\
\text { rRNA mutation genes } \\
\text { Mutational genes } \\
\text { Wild type genes } \\
\text { State on download page when database is updated }\end{array}$ & $(\underline{80}, \underline{81})$ \\
\hline ResFinder & $\begin{array}{l}\text { BLASTn } \\
\text { User selective settings, \% identity and \% coverage } \\
\text { Program sort output according to user selected } \\
\text { thresholds, outputs only best matches. } \\
\text { Possible to analyze assembled data or raw reads } \\
\text { Possible to download: } \\
\text { Results as text } \\
\text { Results as tab separated file } \\
\text { FASTA with hit in genome } \\
\text { FASTA with found resistance genes }\end{array}$ & $\begin{array}{l}\text { FASTA format } \\
\text { One database for each antimicrobial class with } \\
\text { nucleotide sequences for acquired resistance genes } \\
\text { Note file with phenotypic information on resistance } \\
\text { genes } \\
\text { State on homepage and download page when } \\
\text { database is updated }\end{array}$ & $(\underline{65)}$ \\
\hline KmerResistance & $\begin{array}{l}\text { Mapping using } K \text {-mers } \\
\text { Analyses raw reads } \\
\text { Calculates quality of the raw reads and uses this to } \\
\text { set threshold for detected genes } \\
\text { Predicts the species of the genome } \\
\text { Possible to run as web-server or to download } \\
\text { program and run command-line } \\
\text { Possible to run with user-created database }\end{array}$ & Uses the ResFinder database & $(\underline{73})$ \\
\hline SRST2 & $\begin{array}{l}\text { Mapping using Bowtie } 2 \\
\text { Analyzes raw reads } \\
\text { Threshold for detected genes has been set to } 90 \% \\
\text { identity and } 90 \% \text { coverage } \\
\text { Program is downloaded from GitHub and is a } \\
\text { command-line tool (Unix) } \\
\text { Possible to run with user-created database }\end{array}$ & $\begin{array}{l}\text { Can only handle databases in FASTA format with a } \\
\text { specific header format } \\
\text { Choose between the ARG-ANNOT database or the } \\
\text { ResFinder database, the databases is not regularly } \\
\text { updated }\end{array}$ & $(\underline{82})$ \\
\hline
\end{tabular}

RGI; Resistance Gene Identifier. ORF; Open Reading Frame. SNP; Single Nucleotide Polymorphism.

ANNOT system does not detect mutations automatically but outputs the sequence that matches the reference genes so the user is manually able to search from possible mutations. It is also possible for the user to make a custom-made database for specific analysis through ARG-ANNOT.

\section{KmerResistance}

KmerResistance (73) is a mapping tool and is available both as a web server and as a command-line tool.
KmerResistance performs mapping against the ResFinder gene database by examining the number of co-occurring $k$-mers between the raw sequence data and the database. A $k$-mer is a subsequence of the length $k$.

To detect possible resistance gene contaminants, a novel quality validation estimation of the data has been added to minimize false-positive results. This is done by predicting the bacterial species from the genome data, which gives an estimate of both coverage and depth of the data, and thereby the quality of the data. With this 
quality measure of the data, the exponential survival function is used to measure the quality of detected genes. Only genes above the quality threshold set by the exponential survival function are given as output, under the assumption that hits to genes with a significantly lower $k$-mer coverage than the $k$-mer hits to the chromosome originate from contamination as described above.

\section{SRST2}

Short Read Sequence Typing for Bacterial Pathogens (SRST2) (82) is a command-line tool based on the mapping tool Bowtie2 (3). SRST2 maps raw sequence reads directly against an input database of preference, for example, resistance genes. SRST2 also enables further analysis of the identified genes, such as mutations compared to reference sequence. The authors have set the threshold of SRST2 to $90 \%$ identity and $90 \%$ coverage.

In addition to the above-mentioned programs, other programs and methods for detecting AMR genes, not only for single isolates but also for metagenomic samples, are available online for free download, most of them as command-line tools. In the future, comparison of results obtained using the same WGS data set but different programs or tools will be useful to understand the benefits and possible shortcomings of each and to determine whether under certain circumstances some tools will provide more accurate results than others.

\section{Detection of antimicrobial determinants in complex samples}

The tools mentioned above are best suited for the detection of AMR determinants in WGS data from single (pure) isolates, even though they may to some extent also be applicable for complex samples containing whole bacterial communities. However, more dedicated tools for the analysis of DNA samples originating from whole bacterial communities (often called the microbiome) do exist, even though they are still in their infancy. Such microbiome DNA samples are often referred to as whole-community metagenomic samples and should not be confused with traditional metagenomic samples, in which only species-relevant targets such as 16S DNA, are sequenced and used to estimate species distributions in complex samples. The latter is now often referred to as microbial community profiling to avoid confusion with metagenomic sequence analysis. These methods will be able to cover not only bacteria and AMR, but also other pathogens such as viruses, fungi, and parasites. Additionally, part of the sample can also be tested for chemicals/residues in parallel, thus increasing the amount of information about the sample. Analysis of whole-community metagenomic samples can be useful especially for AMR surveillance, but other applications such as rapid investigation of clinical samples have also

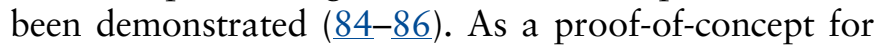
whole-community metagenomics in AMR surveillance, shotgun Illumina sequencing of toilet waste from 18 international airplane flights arriving at Copenhagen Airport, Denmark, was performed and mapped against the ResFinder database using the online tool MGmapper (https://cge.cbs.dtu.dk/services/MGmapper/), which builds on a combination of the Burrows-Wheeler Aligner (BWA) algorithm and SAMtools software packages $(\underline{87}, \underline{88})$. An average of $0.06 \%$ of the reads from the samples were assigned to (known) resistance genes, with genes encoding resistance to tetracycline and macrolide and beta-lactam resistance genes as the most abundant in the samples (9).

An initial challenge is to ensure that a representative sampling is performed and then to ensure that the DNA purification method is able to extract DNA from all species present at an equal ratio, especially if the downstream analysis includes quantification and comparison of (resistance) gene distributions for AMR surveillance. Knudsen and Bergmark recently evaluated eight commercial kits for extracting DNA from three microbiome sample types and found large variation in species composition obtained between the different kits (90). This makes it virtually impossible to compare microbiome data across studies unless the same methodology has been used. DNA extracted from whole-community metagenomic samples covers not only species-related information but all available DNA information present in the sample, including that originating from the host, the environment, and bacteria of interest (74).

The amount and variation of DNA can be extremely high in extractions from whole-community samples, and it is often economically unrealistic to sequence more than a subsample of this, even on the large-capacity second-generation sequencing platforms. However, even if samples are sequenced at high depth it can become time-consuming to process the data generated due to computational requirements. Therefore, it is rare to obtain all available sequence information present in the sample, which makes it difficult to perform de novo assembly prior to analysis for determinants related to reduced susceptibility to antimicrobial agents. Hence, detection of AMR determinants in DNA from complex communities often relies on mapping of raw sequencing reads to gene databases using mapping approaches similar to those mentioned above and is therefore dependent on the quality of these databases. Furthermore, genes such as AMR genes may be harbored by 
organisms that are of low prevalence in the microbiota and may be difficult to detect unless DNA extracted from metagenomics samples is sequenced to a high depth, which currently may not be economically viable beyond specific purposes such as research. However, as next-generation sequencing technologies advance, there is no doubt that these difficulties will be overcome.

\section{MALDI-TOF MS IN RELATION TO AMR}

MALDI-TOF MS is a powerful analytical tool which has only recently been introduced in many clinical laboratories. In short, MALDI-TOF MS is a technique used to analyze biomolecules such as DNA, carbohydrates, proteins, and peptides by their ability to become ionized and enter gas phase and then measuring their time of flight. Here, the mass/charge $(\mathrm{m} / \mathrm{z})$ ratio of the resulting molecular fragments is analyzed to produce a molecular signature. Analysis can be made directly on biological samples of single organisms in standardized or complex matrices including blood and urine, and each spectrum can then be compared to commercial databases containing, e.g., species-specific spectral information, which has proved useful especially for species identification of microorganisms (91). Furthermore, MALDI-TOF MS offers the possibility to detect specific proteins or enzymes as well as smaller biomolecules such as antimicrobial agents and their degradation products (92). The main explanation for the rapid implementation of MALDI-TOF MS in clinical microbiology is probably its ability to generate rapid and relatively reliable results with a high throughput at a low cost. However, considerable cost is required to purchase and maintain the equipment, as is the case with most instrumentation, but once the equipment is acquired, processing each sample is relatively inexpensive. The practical applications of MALDI-TOF MS in relation to detecting AMR can generally be divided into one of three categories, described in detail below.

\section{Species Identification and Targeted Antimicrobial Treatment}

One of the most common applications of MALDI-TOF MS in the clinical microbial laboratory is to perform organism (bacterial species) identification. Application of this method is typically based on the detection of highly abundant proteins in a mass range between 2 and $20 \mathrm{kDa}$ by computing their $\mathrm{m} / \mathrm{z}$ values $(91,93)$. The same level of information can be obtained as from classical culture-based species identification methods, but with MALDI-TOF MS, where results are generated much more rapidly than by culture, hours or even days can be saved in initiating the correct treatment. This can have a direct impact on the clinical outcome as shown by Kumar et al., where the survival rate of septic shock patients decreased by $7.6 \%$ for each hour of delay in antimicrobial administration, for the first 6 hours (94). Therefore, an obvious benefit of rapid organism identification using MALDI-TOF MS is to utilize this information to perform targeted antimicrobial treatment based on a priori knowledge of expected treatment outcomes for each bacterial pathogen or to conduct proper antimicrobial stewardship if no pathogen can be detected in a given sample $(\underline{95}, \underline{96})$.

\section{Direct Detection of AMR Determinants}

A large proportion of AMR determinants are proteins, so it is in principle possible to detect these, or proteolytic fragments of these, directly in the molecular signature from the MALDI-TOF MS, thus providing an on-the-fly resistance profile (97). An initial requirement for this detection is that the resistance genes are actually expressed, which can be an issue in relation to the inducible resistance systems. Initial attempts, however, have not found support for this approach. A study by Schaumann et al., analyzing mass spectra from protein extracts of ESBL-producing and non-ESBL-producing bacteria at the $\mathrm{m} / \mathrm{z}$ range of 2,000 to 20,000 , failed to obtain reliable discrimination between the two populations (98). An alternative approach is to collect spectra from uninduced and induced (by a given antimicrobial agent) cultures and then to perform spectral analysis of these to identify induced peaks in the data (99). A substantial obstacle for both of these methods is that many thousands of resistance protein variants exist, thus making it very difficult to develop specific databases covering all variants, which would need considerable effort and have to be done over time. In addition, signal shielding from nonresistance protein can occur, thus masking the relevant protein signals. This can to some extent be minimized if spectra from protein extracts rather than complete cell extracts are studied and by focusing on a small subset of resistance protein groups such as enzymes involved in resistance to critically important antimicrobial agents such as third-generation cephalosporins and carbapenems $(\underline{100})$.

\section{Detection of Antimicrobial Biomolecules and their Degradation Products}

Because direct detection of resistance proteins by MALDI-TOF MS has not yet proven to be feasible to implement at the clinical laboratory, an alternative 
approach, in which the specific antimicrobial biomolecules and their degradation products resulting from the enzymatic activity are detected by MALDI-TOF MS, has been suggested (100). This approach is targeted to specific enzyme-drug combinations and is again mostly relevant in relation to the subgroup of critically important drugs, which are known to be subjected to enzymatic degradation. Therefore, most studies have examined the feasibility of this approach in relation to carbapenem resistance, as a result of carbapenemase activity, and have shown very high sensitivity and specificity (101, 102). However, one drawback of this approach in the clinical laboratory is that detection of carbapenems such as imipenem and meropenem, and their enzymatic degradation products, relies on a preincubation step to allow time for the degradation process to occur. Another drawback is that the analysis has to be performed at a shorter $\mathrm{m} / \mathrm{z}$ range $(0$ to $700 \mathrm{~m} / \mathrm{z}$ ) than that used for species identification because these molecules are relatively small (103). Implementation at a clinical laboratory as a routine analysis is therefore impeded by the need to reset the MALDI-TOF MS machine several times daily or by investing in two identical machines: one for each purpose (Dennis S. Hansen, unpublished data). A final drawback is the lack of enzymatic inactivation for several of the clinically important antimicrobial agents such as methicillin-resistant $S$. aureus and vancomycin-resistant enterococci, which renders this approach impossible.

\section{DISCUSSION}

This article has demonstrated that molecular methods for characterizing AMR genes are not only important because they provide insight to the possible mechanism of resistance, but are also increasingly becoming commonplace. For example, methods such as PCR are routinely used by laboratories worldwide both for surveillance and for research and are still irreplaceable in terms of cost and throughput compared with other molecular methods. However, methods such as WGS, which are increasingly being used for molecular characterization of AMR determinants and provide a more comprehensive picture of all AMR genes that may be present in an isolate, could supersede PCR in the future if the cost of WGS continues to fall and if analytical processes are further simplified. WGS provides an advantage over methods such as microarray because once isolates are sequenced, the data are in theory available in perpetuity and can be interrogated infinitely with new genes or data sets. In comparison, microarrays, once performed using a set of genes, cannot be interro- gated again for new genes. Designing and printing new primers and probes for genes in silico to update microarrays is not an inconsiderable bioinformatic effort. Any new probe and primer not only have to be specific for that gene, but they also cannot cross-react with any other, and they have to have melting temperatures similar to all other existing probes present on the microarray. In addition, the cost of printing new arrays with new primers and probes often means that these additions are performed as batch updates, so ad hoc immediate response to new outbreaks, such as the global $m c r-1$ outbreak response, is difficult to perform.

However, the rise of WGS and its application in routine AMR surveillance poses the problem of implementation and harmonization of this methodology globally. With some resource-limited countries still struggling to implement simple molecular methods such as PCR in routine surveillance activities, it is unlikely that they will acquire the funds or infrastructure required to perform WGS and ensuing bioinformatic analysis of the data. This will probably affect mitigation and control of AMR, because AMR is a global issue, with new variants likely to arise in different areas of the world but being able to disseminate worldwide due to international trade of food and animals and extensive human travel.

However, with the introduction of WGS, researchers and primary investigators can now have an unprecedented resolution of sequence information, which shifts the workload from running the assay to analyzing the WGS data. Also, for PCR, RT-PCR, and microarrays, results are in most cases either negative or positive, depending on a given cutoff criterion. For instance, a PCR product with the expected size is interpreted as a positive result, even though it may not be $100 \%$ identical at the nucleotide level to the result from the positive control. When analyzing WGS data, if nucleotide variations in the genes of interest are reported, the investigator has to decide (or prove) if the phenotype associated with the reference gene is also applicable to the new variant present in the WGS data. For surveillance and infection control purposes, this may not be of primary concern, but if WGS results are used to guide clinical treatment, matters may be different and require further work to gain experimental proof.

Detection of genetic determinants conferring reduced susceptibility to antimicrobial agents requires application of validated analytical methods and target databases for these genotypic-phenotypic correlations to be fully useful. Combining the right bioinformatic and biological competences often requires interdisciplinary collaboration, where construction of the software algo- 
rithms and target databases are thoroughly documented and validated by the use of well-documented test sets. Furthermore, it is important to ensure that all genetic mechanisms are correctly and comprehensively assigned to particular resistance phenotypes, which are then added to target databases. This is a complex task which requires in-depth knowledge of AMR genes and includes periodic updating and curation of the databases. In addition, a common nomenclature for genes belonging to the same family, and for reporting the results from various analytical tools, is needed if not only WGS data, but also results of WGS data analysis, are to be shared beyond the local setting. Finally, appropriate quality assurance testing protocols to test the quality of all steps of WGS and WGS analysis will need to be developed and implemented routinely in the future. This is an important criterion to ensure that WGS and data interpretation performed from different laboratories are comparable. Similar quality assurance testing protocols have been implemented for a number of phenotypic and molecular tests of isolates by reference laboratories across Europe, e.g., antimicrobial susceptibility testing for Enterobacteriaceae and variable-number tandem repeat testing for Salmonella.

Another important point for consideration of the use of genotypic data for detecting resistance, as discussed by Anjum (9), is that new variants may be overlooked by PCR, microarrays, and WGS, because these detect the presence of genes using primers, probes, and sequences based on prior knowledge. Therefore, as demonstrated by the $m c r-1$ gene (24), resistance to even critical antibiotics may be overlooked if only molecular methods are used. Therefore, it is important to continue to perform both methods in reference laboratories, but care must be taken in correlating genotypic and phenotypic data, as already mentioned, because there may be redundancy, i.e., more than one gene or genetic mechanism that can result in the same phenotype. For instance, continuing with the colistin example, Anjum et al. (27) showed that colistin-resistant E. coli and Salmonella isolates could harbor both the $m c r-1$ gene and single nucleotide polymorphisms in several chromosomal genes associated with colistin resistance that would account for the colistin-resistance phenotype seen in these isolates. Until recently, when only chromosomal changes were known to be associated with colistin resistance, detection of single nucleotide polymorphism variants in relevant chromosomal genes was sufficient to declare colistin resistance to be present in Enterobacteriaceae; researchers did not look further. Because these chromosomal mutations are rarely transferable in nature, it was there- fore deemed safe to use colistin for animal husbandry. However, identification of a transferable plasmid-borne colistin-resistance gene which has been shown to be prevalent worldwide has been a game changer. It has resulted in the recommendation for limited use of colistin in animal husbandry by competent authorities such as the European Medicines Agency (http://www.ema.europa .eu/docs/en_GB/document_library/Scientific_guideline 12016/05/WC500207233.pdf). The impact and risk of the presence of the mor-1 transferable plasmid in Enterobacteriaceae is still being assessed in many countries, including in China, where it was first detected and may have been present for longer than previously known (104).

MALDI-TOF MS is a relatively new method which holds promise and could become more commonplace in the future for AMR characterization, but this requires further exploration and validation of data. An important point for consideration when using this method is the upfront cost of buying MALDI-TOF MS equipment solely for AMR diagnostics, which at current prices may not be cost-effective. It may, however, be cost-effective for use in laboratories where the machine is already available for other purposes. For example, MALDI-TOF MS is used routinely in hospitals and other reference laboratory settings in many countries for rapid identification of bacteria isolated from clinical specimens. If any AMR are present in these isolates that could also be accurately characterized using MALDI-TOF, then it would no doubt aid both rapid clinical diagnosis and treatment of bacterial infections. MALDI-TOF also has the added advantage that it is a "phenotypic" method so in principle should be able to detect new and variant forms of proteins or enzymes that may be responsible for AMRs attributed to bacterial isolates.

This article has undertaken to review some of the most common and popular molecular methods that have been or are currently used by researchers and reference laboratories working with AMR. This review is not an exhaustive list of all approaches available but aims to provide readers, especially those new to the field, with some ideas and examples of work being implemented in this area, and some of the possible pitfalls. Because the field of AMR is an area of growing importance, it is expected that other molecular methods, which are not included in this review, may come to prominence in the future. Microbial community profiling and metagenomic sequence analyses are some of the rapidly developing methods which will probably be used for AMR gene detection in the future, although based on current popularity and convenience, the use of PCR and singleisolate WGS seems irreplaceable. 


\section{REFERENCES}

1. Chan KG. 2016. Whole-genome sequencing in the prediction of antimicrobial resistance. Expert Rev Anti Infect Ther 14:617-619 http://dx .doi.org/10.1080/14787210.2016.1193005.

2. Hollenbeck BL, Rice LB. 2012. Intrinsic and acquired resistance mechanisms in Enterococcus. Virulence 3:421-433 http://dx.doi.org 110.4161/viru.21282.

3. Cox G, Wright GD. 2013. Intrinsic antibiotic resistance: mechanisms, origins, challenges and solutions. Int J Med Microbiol 303:287292 http://dx.doi.org/10.1016/j.ijmm.2013.02.009.

4. Schlessinger D. 1988. Failure of aminoglycoside antibiotics to kill anaerobic, low-pH, and resistant cultures. Clin Microbiol Rev 1:54-59 http://dx.doi.org/10.1128/CMR.1.1.54.

5. Goodwin A, Kersulyte D, Sisson G, Veldhuyzen van Zanten SJ, Berg DE, Hoffman PS. 1998. Metronidazole resistance in Helicobacter pylori is due to null mutations in a gene $(r d x A)$ that encodes an oxygen-insensitive NADPH nitroreductase. Mol Microbiol 28:383-393 http://dx.doi.org 10.1046/j.1365-2958.1998.00806.x.

6. Huovinen P. 2001. Resistance to trimethoprim-sulfamethoxazole. Clin Infect Dis 32:1608-1614 http://dx.doi.org/10.1086/320532.

7. Poirel L, Potron A, Nordmann P. 2012. OXA-48-like carbapenemases: the phantom menace. J Antimicrob Chemother 67:1597-1606 http://dx .doi.org/10.1093/jac/dks121.

8. Boyce JM, Medeiros AA, Papa EF, O’Gara CJ. 1990. Induction of betalactamase and methicillin resistance in unusual strains of methicillinresistant Staphylococcus aureus. J Antimicrob Chemother 25:73-81 http://dx.doi.org/10.1093/jac/25.1.73.

9. Anjum MF. 2015. Screening methods for the detection of antimicrobial resistance genes present in bacterial isolates and the microbiota. Future Microbiol 10:317-320 http://dx.doi.org/10.2217/fmb.15.2.

10. Saiki RK, Gelfand DH, Stoffel S, Scharf SJ, Higuchi R, Horn GT, Mullis KB, Erlich HA. 1988. Primer-directed enzymatic amplification of DNA with a thermostable DNA polymerase. Science 239:487-491 http://dx.doi.org/10.1126/science.2448875.

11. Arya M, Shergill IS, Williamson M, Gommersall L, Arya N, Patel HR. 2005. Basic principles of real-time quantitative PCR. Expert Rev Mol Diagn 5:209-219 http://dx.doi.org/10.1586/14737159.5.2.209.

12. Anjum MF, Lemma F, Cork DJ, Meunier D, Murphy N, North SE, Woodford N, Haines J, Randall LP. 2013. Isolation and detection of extended spectrum $\beta$-lactamase (ESBL)-producing enterobacteriaceae from meat using chromogenic agars and isothermal loop-mediated amplification (LAMP) assays. J Food Sci 78:M1892-M1898 http://dx.doi .org/10.1111/1750-3841.12297.

13. Glais L, Jacquot E. 2015. Detection and characterization of viral species/subspecies using isothermal recombinase polymerase amplification (RPA) assays. Methods Mol Biol 1302:207-225 http://dx.doi.org 10.1007/978-1-4939-2620-6_16.

14. Abdullahi UF, Naim R, Taib WRW, Saleh A, Muazu A, Aliyu S, Baig AA. 2015. Loop-mediated isothermal amplification (LAMP), an innovation in gene amplification: bridging the gap in molecular diagnostics; a review. Indian J Sci Technol 8:1-12.

15. Dallenne C, Da Costa A, Decré D, Favier C, Arlet G. 2010. Development of a set of multiplex PCR assays for the detection of genes encoding important beta-lactamases in Enterobacteriaceae. J Antimicrob Chemother 65:490-495 http://dx.doi.org/10.1093/jac/dkp498.

16. Solanki R, Vanjari L, Subramanian S, B A, E N, Lakshmi V. 2014. Comparative evaluation of multiplex PCR and routine laboratory phenotypic methods for detection of carbapenemases among Gram negative bacilli. J Clin Diagn Res 8:DC23-DC26.

17. Poirel L, Walsh TR, Cuvillier V, Nordmann P. 2011. Multiplex PCR for detection of acquired carbapenemase genes. Diagn Microbiol Infect Dis 70:119-123 http://dx.doi.org/10.1016/j.diagmicrobio.2010.12 .002 .
18. Shen Z, Qu W, Wang W, Lu Y, Wu Y, Li Z, Hang X, Wang X, Zhao D, Zhang C. 2010. MPprimer: a program for reliable multiplex PCR primer design. BMC Bioinformatics 11:143 http://dx.doi.org/10.1186 11471-2105-11-143.

19. Schwartz T, Kohnen W, Jansen B, Obst U. 2003. Detection of antibiotic-resistant bacteria and their resistance genes in wastewater, surface water, and drinking water biofilms. FEMS Microbiol Ecol 43:325335 http://dx.doi.org/10.1111/j.1574-6941.2003.tb01073.x.

20. Lévesque C, Piché L, Larose C, Roy PH. 1995. PCR mapping of integrons reveals several novel combinations of resistance genes. Antimicrob Agents Chemother 39:185-191 http://dx.doi.org/10.1128/AAC.39 .1 .185 .

21. Chagas TP, Alves RM, Vallim DC, Seki LM, Campos LC, Asensi MD. 2011. Diversity of genotypes in CTX-M-producing Klebsiella pneumoniae isolated in different hospitals in Brazil. Braz J Infect Dis 15:420-425 http://dx.doi.org/10.1590/S1413-86702011000500002.

22. Hasman H, Mevius D, Veldman K, Olesen I, Aarestrup FM. 2005. beta-Lactamases among extended-spectrum beta-lactamase (ESBL)resistant Salmonella from poultry, poultry products and human patients in The Netherlands. J Antimicrob Chemother 56:115-121 http://dx.doi .org/10.1093/jac/dki190.

23. Mulvey MR, Bryce E, Boyd DA, Ofner-Agostini M, Land AM, Simor AE, Paton S. 2005. Molecular characterization of cefoxitin-resistant Escherichia coli from Canadian hospitals. Antimicrob Agents Chemother 49:358-365 http://dx.doi.org/10.1128/AAC.49.1.358-365.2005.

24. Liu YY, Wang Y, Walsh TR, Yi LX, Zhang R, Spencer J, Doi Y, Tian G, Dong B, Huang X, Yu LF, Gu D, Ren H, Chen X, Lv L, He D, Zhou H, Liang Z, Liu JH, Shen J. 2016. Emergence of plasmid-mediated colistin resistance mechanism MCR-1 in animals and human beings in China: a microbiological and molecular biological study. Lancet Infect Dis 16:161-168 http://dx.doi.org/10.1016/S1473-3099(15)00424-7.

25. Haenni M, Poirel L, Kieffer N, Châtre P, Saras E, Métayer V, Dumoulin R, Nordmann P, Madec JY. 2016. Co-occurrence of extended spectrum $\beta$ lactamase and MCR-1 encoding genes on plasmids. Lancet Infect Dis 16:281-282 http://dx.doi.org/10.1016/S1473-3099(16)00007 -4.

26. Hasman H, Hammerum AM, Hansen F, Hendriksen RS, Olesen B, Agersø Y, Zankari E, Leekitcharoenphon P, Stegger M, Kaas RS, Cavaco LM, Hansen DS, Aarestrup FM, Skov RL. 2015. Detection of $m c r-1$ encoding plasmid-mediated colistin-resistant Escherichia coli isolates from human bloodstream infection and imported chicken meat, Denmark 2015. Euro Surveill 20:20 http://dx.doi.org/10.2807/1560-7917.ES.2015 .20 .49 .30085 .

27. Anjum MF, Duggett NA, AbuOun M, Randall L, Nunez-Garcia J, Ellis RJ, Rogers J, Horton R, Brena C, Williamson S, Martelli F, Davies R, Teale C. 2016. Colistin resistance in Salmonella and Escherichia coli isolates from a pig farm in Great Britain. J Antimicrob Chemother 71: 2306-2313 http://dx.doi.org/10.1093/jac/dkw149.

28. Duggett NA, Sayers E, AbuOun M, Ellis RJ, Nunez-Garcia J, Randall L, Horton R, Rogers J, Martelli F, Smith RP, Brena C, Williamson S, Kirchner M, Davies R, Crook D, Evans S, Teale C, Anjum MF. 2017. Occurrence and characterization of $m c r-1$-harbouring Escherichia coli isolated from pigs in Great Britain from 2013 to 2015. J Antimicrob Chemother 72:691-695.

29. Nijhuis RH, Veldman KT, Schelfaut J, Van Essen-Zandbergen A, Wessels E, Claas EC, Gooskens J. 2016. Detection of the plasmid-mediated colistin-resistance gene $m c r-1$ in clinical isolates and stool specimens obtained from hospitalized patients using a newly developed real-time PCR assay. J Antimicrob Chemother 71:2344-2346 http:// dx.doi.org/10.1093/jac/dkw192.

30. Veldman K, van Essen-Zandbergen A, Rapallini M, Wit B, Heymans R, van Pelt W, Mevius D. 2016. Location of colistin resistance gene $\mathrm{mcr}-1$ in Enterobacteriaceae from livestock and meat. J Antimicrob Chemother 71:2340-2342 http://dx.doi.org/10.1093/jac/dkw181. 
31. Figueiredo R, Card RM, Nunez J, Pomba C, Mendonça N, Anjum MF, Da Silva GJ. 2016. Detection of an $m c r-1$-encoding plasmid mediating colistin resistance in Salmonella enterica from retail meat in Portugal. J Antimicrob Chemother 71:2338-2340 http://dx.doi.org/10.1093/jac /dkw240.

32. Strommenger B, Kettlitz C, Werner G, Witte W. 2003. Multiplex PCR assay for simultaneous detection of nine clinically relevant antibiotic resistance genes in Staphylococcus aureus. J Clin Microbiol 41:4089-4094 http://dx.doi.org/10.1128/JCM.41.9.4089-4094.2003.

33. Chung Y, Kim TS, Min YG, Hong YJ, Park JS, Hwang SM, Song KH, Kim ES, Park KU. 2016. Usefulness of multiplex real-time PCR for simultaneous pathogen detection and resistance profiling of staphylococcal bacteremia. 2016:6913860.

34. Fang H, Ataker F, Hedin G, Dornbusch K. 2008. Molecular epidemiology of extended-spectrum beta-lactamases among Escherichia coli isolates collected in a Swedish hospital and its associated health care facilities from 2001 to 2006. J Clin Microbiol 46:707-712 http://dx.doi .org/10.1128/JCM.01943-07.

35. Randall LP, Lemma F, Rogers JP, Cheney TE, Powell LF, Teale CJ. 2014. Prevalence of extended-spectrum- $\beta$-lactamase-producing Escherichia coli from pigs at slaughter in the UK in 2013. J Antimicrob Chemother 69:2947-2950 http://dx.doi.org/10.1093/jac/dku258.

36. García-Fernández S, Morosini MI, Marco F, Gijón D, Vergara A, Vila J, Ruiz-Garbajosa P, Cantón R. 2015. Evaluation of the eazyplex® SuperBug CRE system for rapid detection of carbapenemases and ESBLs in clinical Enterobacteriaceae isolates recovered at two Spanish hospitals. J Antimicrob Chemother 70:1047-1050.

37. Kirchner M, Lemma F, Randall L, Anjum MF. 2017. Loop-mediated isothermal amplification (LAMP) for extended spectrum $\beta$-lactamase gene detection in poultry carcase. Vet Rec 181:119.

38. Carter B, Wu G, Woodward MJ, Anjum MF. 2008. A process for analysis of microarray comparative genomics hybridisation studies for bacterial genomes. BMC Genomics 9:53 http://dx.doi.org/10.1186/1471 -2164-9-53.

39. Yu X, Susa M, Knabbe C, Schmid RD, Bachmann TT. 2004. Development and validation of a diagnostic DNA microarray to detect quinolone-resistant Escherichia coli among clinical isolates. J Clin Microbiol 42:4083-4091 http://dx.doi.org/10.1128/JCM.42.9.4083-4091 .2004 .

40. Barl T, Dobrindt U, Yu X, Katcoff DJ, Sompolinsky D, Bonacorsi S, Hacker J, Bachmann TT. 2008. Genotyping DNA chip for the simultaneous assessment of antibiotic resistance and pathogenic potential of extraintestinal pathogenic Escherichia coli. Int J Antimicrob Agents 32: 272-277 http://dx.doi.org/10.1016/j.ijantimicag.2008.04.020.

41. Call DR, Bakko MK, Krug MJ, Roberts MC. 2003. Identifying antimicrobial resistance genes with DNA microarrays. Antimicrob Agents Chemother 47:3290-3295 http://dx.doi.org/10.1128/AAC.47.10.3290 $\underline{-3295.2003 .}$

42. Aarts HJM, Guerra B, Malorny B. 2006. Molecular methods for detection of antimicrobial resistance, p 37-48. In Aarestrup FM (ed), Antimicrobial Resistance in Bacteria of Animal Origin. ASM Press, Washington, DC.

43. Anjum MF, Mafura M, Slickers P, Ballmer K, Kuhnert P, Woodward MJ, Ehricht R. 2007. Pathotyping Escherichia coli by using miniaturized DNA microarrays. Appl Environ Microbiol 73:5692-5697 http://dx.doi .org/10.1128/AEM.00419-07.

44. Card R, Zhang J, Das P, Cook C, Woodford N, Anjum MF. 2013. Evaluation of an expanded microarray for detecting antibiotic resistance genes in a broad range of Gram-negative bacterial pathogens. Antimicrob Agents Chemother 57:458-465 http://dx.doi.org/10.1128/AAC.01223 $\underline{-12 .}$

45. Card RM, Mafura M, Hunt T, Kirchner M, Weile J, Rashid MU, Weintraub A, Nord CE, Anjum MF. 2015. Impact of ciprofloxacin and clindamycin administration on Gram-negative bacteria isolated from healthy volunteers and characterization of the resistance genes they harbor. Antimicrob Agents Chemother 59:4410-4416 http://dx.doi.org /10.1128/AAC.00068-15.

46. Mendonça N, Figueiredo R, Mendes C, Card RM, Anjum MF, da Silva GJ. 2016. Microarray evaluation of antimicrobial resistance and virulence of Escherichia coli isolates from Portuguese poultry. Antibiotics (Basel) 5:5 http://dx.doi.org/10.3390/antibiotics5010004.

47. Szmolka A, Fortini D, Villa L, Carattoli A, Anjum MF, Nagy B. 2011. First report on IncN plasmid-mediated quinolone resistance gene qnrS1 in porcine Escherichia coli in Europe. Microb Drug Resist 17:567-573 http://dx.doi.org/10.1089/mdr.2011.0068.

48. Batchelor M, Hopkins KL, Liebana E, Slickers P, Ehricht R, Mafura M, Aarestrup F, Mevius D, Clifton-Hadley FA, Woodward MJ, Davies RH, Threlfall EJ, Anjum MF. 2008. Development of a miniaturised microarray-based assay for the rapid identification of antimicrobial resistance genes in Gram-negative bacteria. Int J Antimicrob Agents 31:440451 http://dx.doi.org/10.1016/j.ijantimicag.2007.11.017.

49. Szmolka A, Anjum MF, La Ragione RM, Kaszanyitzky EJ, Nagy B. 2012. Microarray based comparative genotyping of gentamicin resistant Escherichia coli strains from food animals and humans. Vet Microbiol 156:110-118 http://dx.doi.org/10.1016/j.vetmic.2011.09.030.

50. Olowe OA, Choudhary S, Schierack P, Wieler LH, Makanjuola OB, Olayemi AB, Anjum M. 2013. Pathotyping bla CTX-M Escherichia coli from Nigeria. Eur J Microbiol Immunol (Bp) 3:120-125 http://dx.doi.org /10.1556/EuJMI.3.2013.2.5.

51. Anjum MF, Choudhary S, Morrison V, Snow LC, Mafura M, Slickers P, Ehricht R, Woodward MJ. 2011. Identifying antimicrobial resistance genes of human clinical relevance within Salmonella isolated from food animals in Great Britain. J Antimicrob Chemother 66:550-559 http://dx .doi.org/10.1093/jac/dkq498.

52. Kirchner M, Abuoun M, Mafura M, Bagnall M, Hunt T, Thomas C, Weile J, Anjum MF. 2013. Cefotaxime resistant Escherichia coli collected from a healthy volunteer; characterisation and the effect of plasmid loss. PLoS One 8:e84142 http://dx.doi.org/10.1371/journal.pone.0084142.

53. Kirchner M, Mafura M, Hunt T, Abu-Oun M, Nunez-Garcia J, Hu Y, Weile J, Coates A, Card R, Anjum MF. 2014. Antimicrobial resistance characteristics and fitness of Gram-negative fecal bacteria from volunteers treated with minocycline or amoxicillin. Front Microbiol 5:722 http://dx .doi.org/10.3389/fmicb.2014.00722.

54. Kirchner M, Mafura M, Hunt T, Card R, Anjum MF. 2013. Antibiotic resistance gene profiling of faecal and oral anaerobes collected during an antibiotic challenge trial. Anaerobe 23:20-22 http://dx.doi.org/10.1016 lj.anaerobe.2013.07.011.

55. Card RM, Warburton PJ, MacLaren N, Mullany P, Allan E, Anjum MF. 2014. Application of microarray and functional-based screening methods for the detection of antimicrobial resistance genes in the microbiomes of healthy humans. PLoS One 9:e86428 http://dx.doi.org /10.1371/journal.pone.0086428.

56. Huehn S, La Ragione RM, Anjum M, Saunders M, Woodward MJ, Bunge C, Helmuth R, Hauser E, Guerra B, Beutlich J, Brisabois A, Peters T, Svensson L, Madajczak G, Litrup E, Imre A, Herrera-Leon S, Mevius D, Newell DG, Malorny B. 2010. Virulotyping and antimicrobial resistance typing of Salmonella enterica serovars relevant to human health in Europe. Foodborne Pathog Dis 7:523-535 http://dx.doi.org/10.1089/fpd .2009 .0447$.

57. Garneau P, Labrecque O, Maynard C, Messier S, Masson L, Archambault M, Harel J. 2010. Use of a bacterial antimicrobial resistance gene microarray for the identification of resistant Staphylococcus aureus. Zoonoses Public Health 57(Suppl 1):94-99 http://dx.doi.org/10.1111 j.1863-2378.2010.01358.x.

58. Perreten V, Kadlec K, Schwarz S, Grönlund Andersson U, Finn M, Greko C, Moodley A, Kania SA, Frank LA, Bemis DA, Franco A, Iurescia M, Battisti A, Duim B, Wagenaar JA, van Duijkeren E, Weese JS, Fitzgerald JR, Rossano A, Guardabassi L. 2010. Clonal spread of 
methicillin-resistant Staphylococcus pseudintermedius in Europe and North America: an international multicentre study. J Antimicrob Chemother 65:1145-1154 http://dx.doi.org/10.1093/jac/dkq078.

59. El-Adawy H, Ahmed M, Hotzel H, Monecke S, Schulz J, Hartung J, Ehricht R, Neubauer H, Hafez HM. 2016. Characterization of methicillinresistant Staphylococcus aureus isolated from healthy turkeys and broilers using DNA microarrays. Front Microbiol 7:2019 http://dx.doi.org /10.3389/fmicb.2016.02019.

60. McManus BA, Coleman DC, Deasy EC, Brennan GI, O’Connell B, Monecke S, Ehricht R, Leggett B, Leonard N, Shore AC. 2015. Comparative genotypes, staphylococcal cassette chromosome mec (SCCmec) genes and antimicrobial resistance amongst Staphylococcus epidermidis and Staphylococcus haemolyticus isolates from infections in humans and companion animals. PLoS One 10:e138079 http://dx.doi.org/10.1371 /journal.pone.0138079.

61. Nimmo GR, Steen JA, Monecke S, Ehricht R, Slickers P, Thomas JC, Appleton S, Goering RV, Robinson DA, Coombs GW. 2015. ST2249MRSA-III: a second major recombinant methicillin-resistant Staphylococcus aureus clone causing healthcare infection in the 1970s. Clin Microbiol Infect 21:444-450 http://dx.doi.org/10.1016/j.cmi.2014.12.018. 62. Schlotter K, Huber-Schlenstedt R, Gangl A, Hotzel H, Monecke S, Müller E, Reißig A, Proft S, Ehricht R. 2014. Multiple cases of methicillinresistant CC130 Staphylococcus aureus harboring mecC in milk and swab samples from a Bavarian dairy herd. J Dairy Sci 97:2782-2788 http://dx .doi.org/10.3168/jds.2013-7378.

63. Piccinini R, Tassi R, Daprà V, Pilla R, Fenner J, Carter B, Anjum MF. 2012. Study of Staphylococcus aureus collected at slaughter from dairy cows with chronic mastitis. J Dairy Res 79:249-255 http://dx.doi.org 110.1017/S002202991200009X.

64. Pilla R, Castiglioni V, Gelain ME, Scanziani E, Lorenzi V, Anjum M, Piccinini R. 2012. Long-term study of MRSA ST1, t127 mastitis in a dairy cow. Vet Rec 170:312 http://dx.doi.org/10.1136/vr.100510.

65. Zankari E, Hasman H, Cosentino S, Vestergaard M, Rasmussen S, Lund O, Aarestrup FM, Larsen MV. 2012. Identification of acquired antimicrobial resistance genes. J Antimicrob Chemother 67:2640-2644 http://dx.doi.org/10.1093/jac/dks261.

66. Gupta SK, Padmanabhan BR, Diene SM, Lopez-Rojas R, Kempf M, Landraud L, Rolain JM. 2014. ARG-ANNOT, a new bioinformatic tool to discover antibiotic resistance genes in bacterial genomes. Antimicrob Agents Chemother 58:212-220 http://dx.doi.org/10.1128/AAC.01310-13. 67. Kwong JC, McCallum N, Sintchenko V, Howden BP. 2015. Whole genome sequencing in clinical and public health microbiology. Pathology 47:199-210 http://dx.doi.org/10.1097/PAT.0000000000000235.

68. Padmanabhan R, Mishra AK, Raoult D, Fournier PE. 2013. Genomics and metagenomics in medical microbiology. J Microbiol Methods 95:415424 http://dx.doi.org/10.1016/j.mimet.2013.10.006.

69. Edwards DJ, Holt KE. 2013. Beginner's guide to comparative bacterial genome analysis using next-generation sequence data. Microb Inform Exp 3:2 http://dx.doi.org/10.1186/2042-5783-3-2.

70. Gargis AS, Kalman L, Berry MW, Bick DP, Dimmock DP, Hambuch T, Lu F, Lyon E, Voelkerding KV, Zehnbauer BA, Agarwala R, Bennett SF, Chen B, Chin EL, Compton JG, Das S, Farkas DH, Ferber MJ, Funke BH, Furtado MR, Ganova-Raeva LM, Geigenmüller U, Gunselman SJ, Hegde MR, Johnson PL, Kasarskis A, Kulkarni S, Lenk T, Liu CS, Manion M, Manolio TA, Mardis ER, Merker JD, Rajeevan MS, Reese MG, Rehm HL, Simen BB, Yeakley JM, Zook JM, Lubin IM. 2012. Assuring the quality of next-generation sequencing in clinical laboratory practice. Nat Biotechnol 30:1033-1036 http://dx.doi.org/10.1038/nbt .2403 .

71. Ellington MJ, Ekelund O, Aarestrup FM, Canton R, Doumith M, Giske C, Grundman H, Hasman H, Holden MT, Hopkins KL, Iredell J, Kahlmeter G, Köser CU, MacGowan A, Mevius D, Mulvey M, Naas T, Peto T, Rolain JM, Samuelsen Ø, Woodford N. 2017. The role of whole genome sequencing in antimicrobial susceptibility testing of bacteria: report from the EUCAST Subcommittee. Clin Microbiol Infect 23:2-22 http://dx.doi.org/10.1016/j.cmi.2016.11.012.

72. Thomsen MC, Ahrenfeldt J, Cisneros JL, Jurtz V, Larsen MV, Hasman H, Aarestrup FM, Lund O. 2016. A bacterial analysis platform: an integrated system for analysing bacterial whole genome sequencing data for clinical diagnostics and surveillance. PLoS One 11:e0157718 http://dx.doi.org/10.1371/journal.pone.0157718.

73. Clausen PT, Zankari E, Aarestrup FM, Lund O. 2016. Benchmarking of methods for identification of antimicrobial resistance genes in bacterial whole genome data. J Antimicrob Chemother 71:2484-2488 http://dx .doi.org/10.1093/jac/dkw184.

74. McArthur AG, Tsang KK. 2017. Antimicrobial resistance surveillance in the genomic age. Ann N Y Acad Sci 1388:78-91 http://dx.doi.org /10.1111/nyas.13289.

75. Sharma M, Nunez-Garcia J, Kearns AM, Doumith M, Butaye PR, Argudín MA, Lahuerta-Marin A, Pichon B, AbuOun M, Rogers J, Ellis RJ, Teale C, Anjum MF. 2016. Livestock-associated methicillin resistant Staphylococcus aureus (LA-MRSA) clonal complex (CC) 398 isolated from UK animals belong to European lineages. Front Microbiol 7:1741 http://dx.doi.org/10.3389/fmicb.2016.01741.

76. Doumith M, Godbole G, Ashton P, Larkin L, Dallman T, Day M, Day M, Muller-Pebody B, Ellington MJ, de Pinna E, Johnson AP, Hopkins KL, Woodford N. 2016. Detection of the plasmid-mediated $\mathrm{mcr}-1$ gene conferring colistin resistance in human and food isolates of Salmonella enterica and Escherichia coli in England and Wales. J Antimicrob Chemother 71:2300-2305 http://dx.doi.org/10.1093/jac/dkw093.

77. Garvey MI, Pichon B, Bradley CW, Moiemen NS, Oppenheim B, Kearns AM. 2016. Improved understanding of an outbreak of meticillinresistant Staphylococcus aureus in a regional burns centre via wholegenome sequencing. J Hosp Infect 94:401-404 http://dx.doi.org/10.1016 j.jhin.2016.09.013.

78. Stoesser N, Batty EM, Eyre DW, Morgan M, Wyllie DH, Del Ojo Elias C, Johnson JR, Walker AS, Peto TE, Crook DW. 2013. Predicting antimicrobial susceptibilities for Escherichia coli and Klebsiella pneumoniae isolates using whole genomic sequence data. J Antimicrob Chemother 68:2234-2244 http://dx.doi.org/10.1093/jac/dkt180.

79. Bradley P, Gordon NC, Walker TM, Dunn L, Heys S, Huang B, Earle S, Pankhurst LJ, Anson L, de Cesare M, Piazza P, Votintseva AA, Golubchik T, Wilson DJ, Wyllie DH, Diel R, Niemann S, Feuerriegel S, Kohl TA, Ismail N, Omar SV, Smith EG, Buck D, McVean G, Walker AS, Peto TE, Crook DW, Iqbal Z. 2015. Rapid antibiotic-resistance predictions from genome sequence data for Staphylococcus aureus and Mycobacterium tuberculosis. Nat Commun 6:10063 http://dx.doi.org/10.1038 Incomms10063.

80. McArthur AG, Waglechner N, Nizam F, Yan A, Azad MA, Baylay AJ, Bhullar K, Canova MJ, De Pascale G, Ejim L, Kalan L, King AM, Koteva K, Morar M, Mulvey MR, O’Brien JS, Pawlowski AC, Piddock LJ, Spanogiannopoulos P, Sutherland AD, Tang I, Taylor PL, Thaker M, Wang W, Yan M, Yu T, Wright GD. 2013. The comprehensive antibiotic resistance database. Antimicrob Agents Chemother 57:3348-3357 http://dx.doi.org/10.1128/AAC.00419-13.

81. McArthur AG, Wright GD. 2015. Bioinformatics of antimicrobial resistance in the age of molecular epidemiology. Curr Opin Microbiol 27:45-50 http://dx.doi.org/10.1016/j.mib.2015.07.004.

82. Inouye M, Dashnow H, Raven LA, Schultz MB, Pope BJ, Tomita T, Zobel J, Holt KE. 2014. SRST2: rapid genomic surveillance for public health and hospital microbiology labs. Genome Med 6:90 http://dx.doi .org/10.1186/s13073-014-0090-6.

83. Langmead B, Salzberg SL. 2012. Fast gapped-read alignment with Bowtie 2. Nat Methods 9:357-359 http://dx.doi.org/10.1038/nmeth .1923 .

84. Hasman H, Saputra D, Sicheritz-Ponten T, Lund O, Svendsen CA, Frimodt-Møller N, Aarestrup FM. 2014. Rapid whole-genome sequencing for detection and characterization of microorganisms directly from clinical 
samples. J Clin Microbiol 52:139-146 http://dx.doi.org/10.1128/JCM .02452-13.

85. Schmieder R, Edwards R. 2012. Insights into antibiotic resistance through metagenomic approaches. Future Microbiol 7:73-89 http://dx .doi.org/10.2217/fmb.11.135.

86. Wang Z, Zhang XX, Huang K, Miao Y, Shi P, Liu B, Long C, Li A. 2013. Metagenomic profiling of antibiotic resistance genes and mobile genetic elements in a tannery wastewater treatment plant. PLoS One 8: e76079 http://dx.doi.org/10.1371/journal.pone.0076079.

87. Li H, Durbin R. 2010. Fast and accurate long-read alignment with Burrows-Wheeler transform. Bioinformatics 26:589-595 http://dx.doi .org/10.1093/bioinformatics/btp698.

88. Li H, Handsaker B, Wysoker A, Fennell T, Ruan J, Homer N, Marth G, Abecasis G, Durbin R, 1000 Genome Project Data Processing Subgroup. 2009. The Sequence Alignment/Map format and SAMtools. Bioinformatics 25:2078-2079 http://dx.doi.org/10.1093/bioinformatics/btp352.

89. Nordahl Petersen T, Rasmussen S, Hasman H, Carøe C, Bælum J, Schultz AC, Bergmark L, Svendsen CA, Lund O, Sicheritz-Pontén T, Aarestrup FM. 2015. Meta-genomic analysis of toilet waste from long distance flights; a step towards global surveillance of infectious diseases and antimicrobial resistance. Sci Rep 5:11444 http://dx.doi.org/10.1038/srep11444.

90. Knudsen BE, Bergmark L. 2016. Impact of sample type and DNA isolation procedure on genomic inference of microbiome composition. mSystems 1:e00095-16. doi:10.1128/mSystems.00095-16.

91. Murray PR. 2012. What is new in clinical microbiology-microbial identification by MALDI-TOF mass spectrometry: a paper from the 2011 William Beaumont Hospital Symposium on molecular pathology. J Mol Diagn 14:419-423 http://dx.doi.org/10.1016/j.jmoldx.2012.03.007.

92. Hrabák J, Chudáčková E, Papagiannitsis CC. 2014. Detection of carbapenemases in Enterobacteriaceae: a challenge for diagnostic microbiological laboratories. Clin Microbiol Infect 20:839-853 http://dx.doi .org/10.1111/1469-0691.12678.

93. Panda A, Kurapati S, Samantaray JC, Srinivasan A, Khalil S. 2014. MALDI-TOF mass spectrometry proteomic based identification of clinical bacterial isolates. Indian J Med Res 140:770-777.

94. Kumar A, Roberts D, Wood KE, Light B, Parrillo JE, Sharma S, Suppes R, Feinstein D, Zanotti S, Taiberg L, Gurka D, Kumar A, Cheang M. 2006. Duration of hypotension before initiation of effective antimicrobial therapy is the critical determinant of survival in human septic shock. Crit Care Med 34:1589-1596 http://dx.doi.org/10.1097/01 .CCM.0000217961.75225.E9.

95. Frickmann H, Masanta WO, Zautner AE. 2014. Emerging rapid resistance testing methods for clinical microbiology laboratories and their potential impact on patient management. BioMed Res Int 2014:375681 http://dx.doi.org/10.1155/2014/375681.
96. Bauer KA, Perez KK, Forrest GN, Goff DA. 2014. Review of rapid diagnostic tests used by antimicrobial stewardship programs. Clin Infect Dis 59(Suppl 3):S134-S145 http://dx.doi.org/10.1093/cid/ciu547.

97. Kostrzewa M, Sparbier K, Maier T, Schubert S. 2013. MALDI-TOF MS: an upcoming tool for rapid detection of antibiotic resistance in microorganisms. Proteomics Clin Appl 7:767-778 http://dx.doi.org /10.1002/prca.201300042.

98. Schaumann R, Knoop N, Genzel GH, Losensky K, Rosenkranz C, Stîngu CS, Schellenberger W, Rodloff AC, Eschrich K. 2012. A step towards the discrimination of beta-lactamase-producing clinical isolates of Enterobacteriaceae and Pseudomonas aeruginosa by MALDI-TOF mass spectrometry. Med Sci Monit 18:MT71-MT77 http://dx.doi.org /10.12659/MSM.883339.

99. dos Santos KV, Diniz CG, Veloso LC, de Andrade HM, Giusta MS, Pires SF, Santos AV, Apolônio AC, de Carvalho MA, Farias LM. 2010. Proteomic analysis of Escherichia coli with experimentally induced resistance to piperacillin/tazobactam. Res Microbiol 161:268-275 http://dx .doi.org/10.1016/j.resmic.2010.03.006.

100. Hrabák J, Chudácková E, Walková R. 2013. Matrix-assisted laser desorption ionization-time of flight (MALDI-TOF) mass spectrometry for detection of antibiotic resistance mechanisms: from research to routine diagnosis. Clin Microbiol Rev 26:103-114 http://dx.doi.org/10.1128 lCMR.00058-12.

101. Burckhardt I, Zimmermann S. 2011. Using matrix-assisted laser desorption ionization-time of flight mass spectrometry to detect carbapenem resistance within 1 to 2.5 hours. J Clin Microbiol 49:3321-3324 http://dx.doi.org/10.1128/JCM.00287-11.

102. Studentova V, Papagiannitsis CC, Izdebski R, Pfeifer Y, Chudackova E, Bergerova T, Gniadkowski M, Hrabak J. 2015. Detection of OXA-48type carbapenemase-producing Enterobacteriaceae in diagnostic laboratories can be enhanced by addition of bicarbonates to cultivation media or reaction buffers. Folia Microbiol (Praha) 60:119-129 http://dx.doi.org /10.1007/s12223-014-0349-8.

103. Chong PM, McCorrister SJ, Unger MS, Boyd DA, Mulvey MR, Westmacott GR. 2015. MALDI-TOF MS detection of carbapenemase activity in clinical isolates of Enterobacteriaceae spp., Pseudomonas aeruginosa, and Acinetobacter baumannii compared against the CarbaNP assay. J Microbiol Methods 111:21-23 http://dx.doi.org/10.1016/j.mimet.2015.01.024.

104. Wang Y, Tian GB, Zhang R, Shen Y, Tyrrell JM, Huang X, Zhou H, Lei L, Li HY, Doi Y, Fang Y, Ren H, Zhong LL, Shen Z, Zeng KJ, Wang S, Liu JH, Wu C, Walsh TR, Shen J. 2017. Prevalence, risk factors, outcomes, and molecular epidemiology of mcr-1-positive Enterobacteriaceae in patients and healthy adults from China: an epidemiological and clinical study. Lancet Infect Dis 17:390-399 http://dx.doi.org /10.1016/S1473-3099(16)30527-8. 